\author{
Ewa Kościałkowska-Okońska \\ Uniwersytet Mikołaja Kopernika w Toruniu \\ ewako@umk.pl
}

\title{
TŁUMACZENIE USTNE: JAKOŚĆ A SKALE OCENY
}

DOI: http://dx.doi.org/10.12775/RP.2018.015

\begin{abstract}
Zarys treści: Tłumaczenie ustne jest zjawiskiem natury społecznej, które realizowane jest w określonym kontekście sytuacyjnym (i kulturowym). Kluczową rolę w komunikacji odgrywa skuteczność, której wartościowanie nie może być sprowadzone wyłącznie do oceny parametrów natury językowej. W niniejszym artykule zostaną przedstawione dwie skale, których celem jest (mierzalna) ocena tłumaczenia możliwa do wykorzystania jako narzędzie w dydaktyce przekładu ustnego, oraz skala proponowana przez autorkę artykułu, stworzona na podstawie własnego doświadczenia dydaktycznego w nauczaniu przekładu ustnego
\end{abstract}

Słowa kluczowe: tłumaczenie ustne, dydaktyka przekładu, ocenianie, kompetencja, jakość

\section{Jakość a dydaktyka przekładu ustnego}

Ywestie związane z kształceniem tłumaczy ustnych stanowią jedną z domen Ibadań nad przekładem ustnym. Zdaniem części badaczy (np. Gile 2000; Pöchhacker 2004) inspiracją dla tych badań była przede wszystkim konieczność rozumienia mechanizmów przekładu ustnego w kontekście edukacji i skutecznych metod nauczania. Na przestrzeni ostatnich kilkunastu lat pojawiło się wiele opracowań i publikacji (a także odbyło się konferencji) poświęconych takim sferom dydaktyki przekładu ustnego jak tworzenie programów nauczania, opracowywanie kryteriów oceny oraz metod dydaktycznych. Ponadto badania nad dydaktyką przekładu ustnego mają charakter interdyscyplinarny, w dużej mierze czerpiąc ze zdobyczy psychologii kognitywnej (np. Moser-Mercer 2000, 2007, 2008) czy podejścia socjo-konstruktywistycznego 
(np. Kiraly 1995, 2000). Co więcej, przedmiotem badań, a jednocześnie źródłem danych w tej dziedzinie są adepci sztuki przekładu na różnego rodzaju studiach tłumaczeniowych ( $w$ trakcie programów licencjackich, magisterskich czy podyplomowych). Udział studentów jest cenny również z innego punktu widzenia, mianowicie pozwala na dążenie przez prowadzącego zajęcia (mentora, trenera) do osobistej (krytycznej) refleksji nad stosowanymi metodami nauczania, ich efektywnością, a także potencjalnym udoskonaleniem tychże metod w celu osiągnięcia lepszych wyników rozumianych jako tworzenie tekstów na odpowiednio wysokim poziomie językowo-merytorycznym przez studentów studiów tłumaczeniowych w zakresie przekładu ustnego. Innymi słowy tłumaczenia studentów powinny być odpowiedniej jakości, aby mogły być akceptowane nie tylko z punktu widzenia zajęć i programu nauczania, ale także $\mathrm{w}$ sensie przekazu o odpowiednim nasyceniu informacyjnym i zgodności z oryginałem. Pojęcie jakości jest zatem niezwykle istotne dla naszych rozważań i dlatego też zasługuje na krótkie omówienie.

Jakość w przekładzie ustnym to temat badawczo znaczący w przekładoznawstwie już mniej więcej od lat 80. ubiegłego stulecia. W dyskusjach i rozważaniach nad jakością często pojawiają się zagadnienia związane ze sposobami i metodologią jej oceny, a tym samym z problemem obiektywizmu takiego działania. Klasyczna definicja przekładu (pisemnego i ustnego) mówi, że należy dokonać (adekwatnego) transferu zawartości przekazu w języku źródłowym (na różnych poziomach języka) do języka docelowego. Priorytetem przekładu ustnego zatem jest skuteczna komunikacja (w relacji słuchacz-mówca), która stanowi gwarancję osiągnięcia tak założonego rezultatu. Innymi słowy dobry przekład i skuteczna komunikacja zapewniają odpowiednią jakość tłumaczenia.

Relacje pomiędzy tłumaczem a odbiorcą tłumaczenia determinują niejako ustalenie kryteriów jakości, co umożliwia pewną systematyzację cech uznawanych za typowe dla przekładu dobrej jakości. Badacze tacy jak Bühler (1986), Kurz (1989, 1993), Marrone (1993), Kopczyński (1994), Moser (1995), Mesa (2000), Kadric, Kaindl i Pöchhacker (2000), Collados Aís i García Becerra (2015) czy Pöchhacker $(2000,2013)$ w swoich badaniach empirycznych starali się opisać takie kryteria w sposób bardziej szczegółowy. Co charakterystyczne, można zaobserwować dużą powtarzalność kryteriów jakości wskazanych w kwestionariuszach różnych badaczy; widać tym samym, jak istotne znaczenie przywiązuje się właśnie do tych cech przekładu. Najczęściej wymieniane kryteria to: płynność wypowiedzi, logiczna spójność wypowiedzi, zgodność z treścią oryginału, kompletność wypowiedzi, poprawne użycie struktur gramatycznych, zastosowanie poprawnej termino- 
logii, zastosowanie odpowiedniego stylu, dokładne przygotowanie materiałów konferencyjnych, wytrzymałość, opanowanie, miły wygląd, rzetelność, umiejętność pracy w zespole, przyjemny głos, pozytywne opinie uczestników konferencji/słuchaczy czy też brak silnego akcentu. Widać więc wyraźnie, jak ważna jest dokładność wypowiedzi i jej zgodność z treścią oryginału, a także jasność oraz precyzja wypowiedzi.

Tworzenie i opracowanie jednolitego i skonsolidowanego systemu kryteriów napotyka trudności: identyfikacja kryteriów charakteryzuje się sporą dynamiką $\mathrm{z}$ uwagi na zmieniające się priorytety badawcze, a $\mathrm{z}$ drugiej strony zjawisko samo w sobie jest w dużej mierze względne i jednak subiektywne, zależne od indywidualnych preferencji osoby dokonującej oceny. Jakość można oceniać z perspektywy różnych metod, którym przyświecają takie cele jak zaspokojenie potrzeb czy spełnienie oczekiwań użytkowników tłumaczenia. Równie istotny jest fakt, że tłumaczenie ustne to zjawisko natury społecznej, realizowane w określonym kontekście sytuacyjnym (i kulturowym), w którym skuteczna komunikacja odgrywa kluczową rolę, natomiast orzekanie o tej skuteczności nie może się sprowadzać wyłącznie do oceny parametrów natury językowej. Ponadto zauważalny brak precyzji w specyfikowaniu ram kryteriów (czy też nawet ich wartości granicznych, zob. skale oceniania Lee 2008, do których wrócimy w dalszej części artykułu) oraz częste nakładanie się deskryptorów w jeszcze bardziej znaczącym stopniu utrudniają opracowanie konkretnych i - co niezwykle ważne - mierzalnych wartości.

W wypadku przekładu ustnego odczuwalny jest deficyt badań nad oceną i kryteriami jakości. Wynika to $\mathrm{w}$ dużym stopniu $\mathrm{z}$ samego charakteru tłumaczenia ustnego, które jako działanie językowe jest ulotne (w przeciwieństwie do przekładu pisemnego, gdzie badacz ma możliwość przeprowadzenia dogłębnej analizy tekstu). Należy również wspomnieć o trudnościach z uzyskaniem materiału, który można by w trakcie późniejszych badań analizować - nie wszystkie sytuacje tłumaczeniowe (np. konferencja czy też spotkanie biznesowe) stwarzają możliwość uczestniczenia w procesie tłumaczenia osobom trzecim (np. badaczowi). Trudno jest zatem mówić w takim wypadku o specyfikacji kryteriów, a następnie wynikającej z tego weryfikacji konkretnych parametrów jakościowych. Istotne jest również to, że mamy do czynienia ze swoistym paradoksem jakościowym, który niewątpliwie utrudnia mierzenie kryteriów i wskaźników jakości. Paradoks ten polega na istnieniu dwóch perspektyw, z którymi ma do czynienia tłumacz ustny w trakcie wykonywania swojej pracy: $\mathrm{z}$ jednej strony musi w swoim tłumaczeniu dochować wierności oryginałowi i być „niewidzialnym” (a zatem neutralnym kanałem przekazu informacji), z drugiej jednak strony powinien działać 
jako mediator kulturowy funkcjonujący w obu kulturach i rzeczywistościach językowych, którego zadaniem jest monitorowanie i kontrola komunikacji oraz potencjalne doskonalenie - jeżeli zajdzie taka potrzeba - jasności, sensu i precyzji przekazu. Cel i rodzaj zadania tłumaczeniowego jest determinantą wymagań jakościowych. Kryteria jakości można oczywiście dalej uszczegółowić (w sposób pozwalający na włączenie subkomponentów w zakres danego kryterium), natomiast należy zwrócić uwagę, aby proces dalszego precyzowania nie oznaczał wymieniania niezliczonych cech przynależnych danemu zakresowi jakości.

\section{Rola nauczyciela i skale oceniania}

Podniesione wyżej zagadnienie osobistej i krytycznej refleksji nauczyciela ma bardzo duże znaczenie w kontekście jego roli w procesie dydaktycznym: powinien być mentorem lub przewodnikiem (por. również Tryuk 2012), którego zadaniem jest pokazywanie potencjalnych rozwiązań problemów pojawiających się w trakcie wykonywania zadań, a także sposobów radzenia sobie z nowymi i nieznanymi sytuacjami, tak aby studenci mogli na tej podstawie budować swoje doświadczenie, a tym samym wykształcić poczucie odpowiedzialności za własną pracę oraz współodpowiedzialności za efektywny proces dydaktyczny. W literaturze przedmiotu kwestią cech, umiejętności i kompetencji, którymi powinien charakteryzować się nauczyciel, zajmowali się tacy badacze jak na przykład Colina (2003), Kelly (2005), Gouadec (2007) czy Englund Dimitrova (2002), która przykłada bardzo dużą wagę do roli nauczyciela w dydaktyce przekładu. Jak zauważa, nauczyciel powinien być nie tylko teoretykiem, ale również - a może przede wszystkim - praktykiem, gdyż tylko taka perspektywa pozwala na wykształcenie świadomości mechanizmów, wyzwań i wymagań inherentnych dla procesu tłumaczeniowego i dla zawodu tłumacza.

Z punktu widzenia jakości tłumaczenia oraz jej oceny w kontekście dydaktycznym należy zwrócić uwagę na fakt, że każdy nauczyciel może wypracować własne i dostosowane do studentów (oraz przedmiotu i osobistych wymagań) kryteria, co przekłada się na intuicyjność i subiektywność oceny (por. adekwatność i rzetelność oceny, Sawyer 2004: 100; Lee 2008: 173). Wypracowanie takiego zestawu kryteriów jest niezwykle istotne w dydaktyce przekładu - w dalszej części artykułu zostaną przedstawione dwie już istniejące skale, których celem jest (mierzalna) ocena tłumaczenia możliwa do wykorzystania jako narzędzie w dydaktyce przekładu ustnego, oraz skala 
proponowana przez autorkę artykułu, stworzona na podstawie doświadczenia dydaktycznego w nauczaniu przekładu ustnego.

Pierwsza skala została stworzona przez Riccardi (2002), która wysuwa postulat wprowadzenia do oceny makro- i mikrokryteriów. Należy wspomnieć, że stosowane przez Riccardi makrokryteria stanowią odzwierciedlenie propozycji Viezziego (1996), który uważał, że skuteczna komunikacja w przekładzie ustnym jest wypadkową czterech zakładanych cech przekładu: równoważności (ekwiwalencji), odpowiedniości, dokładności oraz użyteczności; cechy te mają służyć komunikacji między językami i kulturami (Viezzi 1996: 77). Odpowiedniość i użyteczność związane są z relacją istniejącą pomiędzy tekstem źródłowym a jego odbiorcą w konkretnej sytuacji komunikacyjnej, natomiast ekwiwalencja i dokładność dotyczą relacji pomiędzy tekstem źródłowym a docelowym (Viezzi 1996: 119). Podstawą do wypracowania przez Riccardi mikrokryteriów były kwestionariusze (przeprowadzone w SSLMIT w Trieście) dla tłumaczenia symultanicznego i konsekutywnego. Oba kwestionariusze obejmują 15 kryteriów językowych i elementów dotyczących tłumaczenia ustnego i mogą zostać wykorzystane do zbadania wśród studentów tych domen kompetencji, w obrębie których widać pewne deficyty. Mikrokryteria dotyczą odstępstw fonologicznych, prozodycznych, związanych z danym aktem tłumaczeniowym, przerw, odstępstw leksykalnych, morfosyntaktycznych, logiczno-semantycznych, dodawania treści, pomijania, reformulacji treści, stosowanych rejestrów języka, technik, skutecznych rozwiązań czy też wreszcie ogólnego wrażenia. W kwestionariuszach pojawiły się również dwa dodatkowe mikrokryteria dla tłumaczenia konsekutywnego: kontakt wzrokowy oraz gestykulacja i postawa w trakcie wykonywania tłumaczenia. Riccardi umieszcza mikrokryteria w strukturze makrokryteriów, a zatem dokładność jest rezultatem dokonania odpowiedniego wyboru na poziomie leksykalnym, prozodycznym i morfosyntaktycznym, natomiast odpowiedniość dotyczy takich mikrokryteriów jak rejestr czy odstępstwa logiczno-semantyczne (Riccardi 2002: 124).

Riccardi dostrzega pewną arbitralność swojej skali, natomiast warto odnotować, że kwestionariusz skupia się na błędach popełnionych przez tłumacza; co więcej, nie ma w nim struktury hierarchizującej czynniki względem stopnia ich istotności dla tłumaczenia (od mniej istotnych po te najbardziej istotne). Co naturalne, nie wszystkie wymienione kryteria są $\mathrm{w}$ identyczny sposób znaczące dla przekazu treści. Ponadto - co już stanowi ważki problem w praktycznym stosowaniu skali - liczba kryteriów jest duża, a więc ich rzeczywista ocena w trakcie zajęć lub egzaminu może okazać się mało realna. 
Drugi model skali został zaproponowany przez Lee (2008), która w pewnej mierze odwołuje się do badania Pöchhackera (2001) postulującego cztery podstawowe kryteria oceny $\mathrm{w}$ dwóch wymiarach, a mianowicie, na płaszczyźnie pragmatycznej - ekwiwalentność zamierzonego efektu oraz skuteczną interakcję komunikacyjną, a na płaszczyźnie leksykalno-semantycznej - dokładne przekazanie treści i zastosowanie odpowiednich ekwiwalentów w języku docelowym (Pöchhacker 2001: 413). Lee słusznie zauważa, że w warunkach nie do końca przypominających autentyczną sytuację tłumaczeniową (a niewątpliwie zajęcia można uznać za warunki w znacznym jednak stopniu laboratoryjne) ocena kompetencji społecznych czy skuteczności komunikacyjnej jest utrudniona. Stąd też wynika jej postulat, aby w skali oceny zawrzeć elementy takie jak dokładność, jakość tekstu docelowego oraz sposób jego prezentacji. Dokładność oznacza przekazanie treści komunikatu w języku źródłowym na język docelowy i nie dotyczy wyłącznie leksykalnych podobieństw pomiędzy oryginałem a tłumaczeniem, a raczej odnosi się do uzyskania podobnego efektu na odbiorcach docelowych, jaki tekst oryginału wywiera na odbiorcach źródłowych. Jakość języka docelowego związana jest $\mathrm{z}$ przekazem treści $\mathrm{w}$ rozumieniu poprawności językowej, naturalności brzmienia czy też odpowiedniości języka w danym kontekście, czyli na przykład fonologii, składni, morfologii, rejestru i stylu. Sposób prezentacji dotyczy umiejętności występowania publicznego oraz prezentacji bez odniesień do spraw językowych. Zawierają się w tej kategorii takie kwestie jak sposób artykulacji, brak przerw w mówieniu, wahania, dodatkowe dźwięki, nadmierne poprawianie się czy sposób operowania głosem (inne czynniki niewerbalne, takie jak kontakt wzrokowy czy postawa w trakcie tłumaczenia, można oceniać tylko na podstawie nagrania wizualnego). Analityczność skali Lee (2008: 171) polega na tym, że umożliwia ona określenie poziomu jakości tłumaczenia przez porównanie tego poziomu z opisem danego kryterium przyjętego w skali.

Każde z kryteriów (dokładność, jakość tekstu docelowego i sposób prezentacji) odnosi się do trzech płaszczyzn, a mianowicie rozumienia ze słuchu, stopnia znajomości języka oraz umiejętności występowania publicznego w zakresie 0-6 punktów. Pierwsze kryterium - dokładność - obejmuje dokładność przekazania treści komunikatu przy zachowanej ekwiwalencji semantycznej i pragmatycznej (czyli jakość tłumaczenia), co prowadzi do uzyskania identycznego znaczenia i założonego efektu komunikacyjnego. Odstępstwa od tekstu źródłowego, polegające na przykład na pomijaniu lub dodawaniu pewnych elementów czy też nie do końca uzasadnionych zmianach znaczenia, powinny być analizowane z uwagi na ich znaczący wpływ na 
logikę i spójność tłumaczonego tekstu, a także adekwatne przekazanie treści. Z kolei jakość tłumaczenia na tekst docelowy powinna być wyrazem poprawności językowej oraz dostosowania do kontekstu. Pewne odstępstwa od poprawności językowej mogą być związane na przykład z niewłaściwą wymową, akcentem, deficytem poprawności gramatycznej, interferencją z języka źródłowego czy też użyciem niewłaściwego rejestru. Sposób prezentacji - czyli ostatnie kryterium - zawiera w sobie takie komponenty jak jakość wystąpień publicznych czy skuteczna komunikacja; odstępstwa mogą dotyczyć na przykład przerw, wahań, monotonnej intonacji czy wolnego tempa mówienia.

W ocenie Lee każde z kryteriów otrzymuje przynależne punkty z uwagi na zakres realizacji danego komponentu. Ewentualne zastrzeżenia mogą wynikać z faktu, że poszczególne komponenty są w określony sposób oceniane: na przykład w kryterium dokładności maksymalna punktacja (6 pkt) jest przewidziana za „całkowite zrozumienie treści tekstu oryginalnego", natomiast niższa punktacja obowiązuje przy „dobrym zrozumieniu treści tekstu oryginalnego" (Lee dodatkowo wyjaśnia, że w tłumaczeniu zaobserwowano pewne odstępstwa od oryginału, ale nie mają one dużego znaczenia dla ogólnej spójności tekstu). Powstaje zatem pytanie, na czym polega różnica pomiędzy wspomnianym „całkowitym” a „dobrym” zrozumieniem testu. Te podobne $\mathrm{w}$ dużej mierze określenia $\mathrm{w}$ pewien sposób ulegają pojęciowemu rozmyciu. Pozytywny przekaz określenia „dobre” oznacza przecież realizację kryteriów założonych dla danej kategorii. Dolne ramy punktacji są w podobny sposób niedookreślone, ponieważ w tym samym kryterium pojawiają się określenia „niewłaściwe” i „słabe”, odnoszące się do zrozumienia tekstu oryginalnego - jeżeli tłumaczenie jest „niewłaściwe”, to z dużą dozą prawdopodobieństwa można je traktować jako tłumaczenie słabej jakości.

Nieco rozmyte są również oceny pozostałych dwóch kryteriów. W przypadku poprawności językowej mamy do czynienia za „znakomitą” i „bardzo dobrą" znajomością języka, natomiast określenie zakresu ocen na dobrą sprawę niewiele się różni (w pierwszym przypadku zakres mówi o „niewielu błędach językowych”, a w drugim - o „kilku drobnych błędach językowych”, natomiast błędy te nie stanowią przeszkody w zrozumieniu tekstu). Podobnie przy występowaniu publicznym widać „doskonały sposób prezentacji/komunikacji” i „bardzo dobry sposób prezentacji/komunikacji”), czyli znowu określenia są znaczeniowo bardzo do siebie zbliżone.

Skala Lee jest w zdecydowanym stopniu zorientowana na produkt; jej walidacja oraz transpozycja na wartości uniwersalne dla dydaktyki przekładu siłą rzeczy wymagałaby jednak ewaluacji kryteriów procesowych, w tym takich zdolności poznawczych jak na przykład wiedza czy kompetencja. 
Należy jednak stwierdzić, że pomimo pojawiających się (i nieuchronnych w przypadku skal analitycznych) deficytów skala Lee jest istotnym krokiem w kierunku modelu oceny tłumaczenia ustnego, który można wykorzystać $\mathrm{w}$ dydaktyce przedmiotowej.

$\mathrm{W}$ analizie powyższych skal widać wyraźnie, że z zasady przykładowa skala oceny powinna być raczej zorientowana na proces niż na produkt. Jest to niewątpliwie warunkiem stopniowego acz stałego rozwoju; innymi słowy, kompetencja tłumacza ulega zwiększeniu, poczynając od etapu początkującego tłumacza poprzez ciągły rozwój w kierunku profesjonalisty, czyli tłumacza posiadającego odpowiednią wiedzę i doświadczenie pozwalające na tworzenie tekstów wysokiej jakości. Warto jednak zaznaczyć, że taka skala nie powinna zawierać w sobie zbyt wielu kategorii, podkategorii, klas i podklas lub kryteriów i subkryteriów, ponieważ rezultatem takiego rozmycia pojęciowego jest brak ostrości kategorii i klas oraz nadmierna intuicyjność oceny. Trudno jest ponadto ująć w ocenie wszystkie aspekty, które mają znaczenie dla tłumaczenia, ponieważ rzetelna i wiarygodna ocena kilkunastu komponentów w tłumaczeniu studenta w czasie rzeczywistym jest praktycznie niewykonalna. Widoczne w formularzach ocen czy zakresach skal oceny multiplikowanie kryteriów nie do końca się sprawdza ze względu na fakt, że drobne i subtelne różnice pomiędzy poszczególnymi kryteriami zawierającymi się w jednej płaszczyźnie językowej (chociażby właściwy rejestr czy styl wypowiedzi) nie zawsze są zrozumiałe dla osoby ocenianej. Taka pedagogiczna ocena powinna być:

1) przyjazna użytkownikom rozumiejącym i akceptującym kryteria oceny;

2) praktyczna i łatwa do weryfikacji dla nauczyciela oraz dopasowana do etapu rozwoju kompetencji tłumaczeniowej danego studenta, ponieważ - co oczywiste - student nie jest tłumaczem profesjonalnym.

Proponowałabym zatem czteroelementowy wstępny model kryteriów oceny (w kontekście pedagogicznym), który przedstawiałby się w następujący sposób:

1) Kryterium kompetencji językowej - obejmuje stosowanie prawidłowych struktur gramatycznych i leksykalnych, odpowiedniej terminologii, zasad retoryki oraz pragmatyki językowej. Zakres punktowy waha się od 1 do 3, gdzie 3 to kompetencja językowa na bardzo dobrym poziomie, zbliżonym do poziomu rodzimego użytkownika języka, z zastosowaniem wymienionych struktur. 2 oznacza kompetencję językową na poziomie odpowiednim, umożliwiającym zrozumienie przez użytkowników tekstu tłumaczenia; w tłumaczeniu 
mogą wystąpić nieznaczne deficyty natury gramatycznej, leksykalnej, terminologicznej czy stylistycznej, ale nie uniemożliwiają one zrozumienia tekstu. 1 oznacza zaś kompetencję językową na poziomie nieodpowiednim, uniemożliwiającą zrozumienie tekstu w każdej płaszczyźnie językowej. Kryterium stanowi 30\% całej oceny.

2) Kryterium kompetencji pozajęzykowej - odnosi się do wiedzy ogólnej, z jej nieodłącznym składnikiem, którym jest wiedza kulturowa. Zakres punktowy waha się od 1 do 3, gdzie 3 odpowiada bardzo dobrej kompetencji pozajęzykowej na poziomie zbliżonym do poziomu rodzimego użytkownika języka. 2 punkty oznaczają, podobnie jak w przypadku kompetencji językowej, kompetencję na odpowiednim poziomie, umożliwiającym zrozumienie pozajęzykowego kontekstu tłumaczenia (oraz zawartych w tekście źródłowym elementów kulturowych i umiejętność ich prawidłowego przełożenia na język docelowy). Pojawiające się nieścisłości nie mogą w znaczący sposób utrudniać rozumienia tłumaczonego tekstu. 1 to kompetencja językowa na nieodpowiednim i niewystarczającym poziomie, która nie pozwala na przetłumaczenie zawartych w tekście oryginału elementów pozajęzykowych. Powyższe kryterium stanowi 30\% całej oceny.

3) Kryterium znajomości warsztatu tłumacza - zawiera znajomość zasad etyki zawodowej czy też techniki prezentacji tekstu obejmujące komunikację niewerbalną. Zakres punktowy waha się od 1 do 3 : 3 punkty można otrzymać za bardzo dobry sposób realizacji wymienionych powyżej kryteriów; 2 punkty oznaczają niedociągnięcia czy braki, jednakże niemające znaczącego wpływu na percepcję tłumaczenia; 1 punkt to nieodpowiednia znajomość warsztatu, prowadząca do negatywnego odbioru tłumaczenia przez jego użytkowników. Kryterium stanowi $20 \%$ całej oceny.

4) Kryterium strategii tłumaczeniowych - dotyczy umiejętności rozwiązywania problemów na podstawie posiadanego doświadczenia, oceny procesu jako całości, jak również poszczególnych jego elementów. Zakres punktowy waha się od 1 do 3: 3 punkty oznaczają bardzo dobrą umiejętność stosowania strategii tłumaczeniowych; 2 punkty można otrzymać za umiejętność stosowania strategii tłumaczeniowych w taki sposób, że nawet przy deficytach tłumaczony tekst jest zrozumiały dla odbiorców; 1 punkt to brak umiejętności zastosowania strategii tłumaczeniowych. Kryterium strategii tłumaczeniowych stanowi $20 \%$ całej oceny. 
Należy również podkreślić, że warto $\mathrm{w}$ ocenie stworzyć osobną kategorię, na przykład w postaci rubryki, na pozytywną informację zwrotną dla studenta i notowanie wszelkich interesujących i kreatywnych rozwiązań tłumaczeniowych - pamiętajmy, że sama krytyka, nawet jeżeli jest najbardziej konstruktywna, dla niektórych studentów może mieć działanie demotywujące i zniechęcające ( $w$ takiej sytuacji można nieco zmienić proporcje procentowe wiążące się z realizacją danego kryterium w obrębie skali oceny).

Można oczywiście dążyć do dalszego uszczegółowienia kryteriów, natomiast warto pamiętać, aby nie oznaczało to tworzenia niekończących się list komponentów lub subkomponentów, które miałyby być realizowane $\mathrm{w}$ danym zakresie poddanym ocenie. Ocena przeprowadzana jest na podstawie wyników pracy studenta $\mathrm{w}$ trakcie zadań tłumaczeniowych na zajęciach (można prowadzić również ocenę grupową (np. w ramach oceny formatywnej, por. Kościałkowska-Okońska 2017).

\section{Uwagi końcowe}

W dydaktyce przekładu ustnego ocena tłumaczeń oraz analiza ich jakości to zjawiska złożone i rodzące wiele problemów. Przyjęcie płaszczyzn kompetencyjno-warsztatowych jako podstawowych ram oceniania, jak przewiduje to powyższy model, może być pomocne w skupieniu się na tych domenach, które mają priorytetowe znaczenie nie tylko dla samej jakości przekładu, ale także dla kształcenia przyszłych tłumaczy z perspektywy monitorowania ich produkcji oraz przekazywania informacji zwrotnej. Stopniowe dochodzenie do etapu tworzenia dobrego jakościowo przekładu spełniającego wymagania dokładności, adekwatności i spójności jest wynikiem interaktywnego działania czy wręcz przenikania się kompetencji językowych, pozajęzykowych, technik i strategii tłumaczeniowych. Nauczanie przekładu ustnego to również pokazanie drogi do rozwoju własnych kompetencji i umiejętności. Nauczyciel zatem jest odpowiedzialny za przekazywanie i dzielenie się własną wiedzą, kompetencjami i doświadczeniem, jeżeli chodzi o podejmowanie decyzji i rozwiązywanie problemów, pracę w zespole, radzenie sobie ze stresem czy umiejętność odnalezienia się w różnych trudnych i nieoczekiwanych sytuacjach zawodowych. Program kształcenia przedmiotowego w zakresie tłumaczenia ustnego powinien więc być dostosowany do dynamiki rynku pracy, jego potrzeb i oczekiwań. Z drugiej strony ważne jest też, aby rozwijał umiejętność krytycznego i refleksyjnego myślenia, która jest niezwykle ważna w każdym zawodzie, a w zawodzie tłumacza ustnego w szczególności. 


\section{Literatura}

Bühler, H., 1986, „Linguistic (semantic) and extra-linguistic (pragmatic) criteria for the evaluation of conference interpretation and interpreters", [w:] Multilingua 5, nr 4, s. 231-235.

Colina, S., 2003, Translation Teaching: From Research to The Classroom, New York - San Francisco.

Collados Aís, A., García Becerra, O., 2015, „Quality”, [w:] The Routledge Handbook of Interpreting, H. Mikkelson, R. Jourdenais (red.), London New York, s. 368-383.

Englund Dimitrova, B., 2002, „Training and Educating the Trainers - A Key Issue in Translators' Training", [w:] Teaching Translation and Interpreting 4, E. Hung (red.), Amsterdam-Philadelphia, s. 73-82.

Gile, D., 2000, „The history of research into conference interpreting: A scientometric approach", [w:] Target, nr 12(2), s. 297-321.

Gouadec, D., 2007, Translation as a profession, Amsterdam-Philadelphia.

Kadric, M., Kaindl, K., Pöchhacker, F. (red.), 2000, Translationswissenschaft, Tübingen.

Kelly, D., 2005, A Handbook for Translator Trainers. A Guide to Reflective Practice, Manchester.

Kiraly, D., 1995, Pathways to Translation. Pedagogy and Process, Kent, Ohio.

Kiraly, D., 2000, A Social Constructivist Approach to Translator Education: Empowerment from Theory to Practice, Manchester.

Kopczyński, A., 1994, „Quality in conference interpreting: Some pragmatic problems", [w:] Bridging the gap. Empirical Research in simultaneous interpretation, S. Lambert, B. Moser-Mercer (red.), Amsterdam-Philadelphia, s. 87-100.

Kościałkowska-Okońska, E., 2017, „Setting assessment objectives vs assessment criteria in the context of teaching specialist translation", [w:] Translatorik, Translationsdidaktik und Fremdsprachendidaktik. Herausforderungen und Perspektiven, Frankfurt am Main - Bern - Bruxelles New York - Oxford - Warszawa - Wien, s. 63-70.

Kurz, I., 1989, „Conference Interpreting: User Expectations”, [w:] Coming of Age: Proceedings of the $30^{\text {th }}$ Annual Conference of the American Translators Association, D.L. Hammond (red.), Medford - New Jersey, s. 143-148.

Kurz, I., 1993, „Conference Interpretation: Expectations of different user groups", [w:] The Interpreter's Newsletter., nr 5, Universita degli Studi di Trieste, s. 13-21. 
Lee, J., 2008, „Rating Scales for Interpreting Performance”, [w:] The Interpreter and Translator Trainer, nr 2(2), s. 165-184.

Marrone, S., 1993, „Quality: A Shared Objective”, [w:] The Interpreter's Newsletter, nr 5, s. 35-41.

Mesa, A.-M., 2000, „The Cultural Interpreter: An Appreciated Professional. Results of a Study on Interpreting Services: Client, Health Care Worker and Interpreter Points of View", [w:] The Critical Link 2: Interpreters in the Community, R. Roberts, S.E. Carr (red.), Amsterdam-Philadephia, s. $67-79$.

Moser, P., 1995, „Simultanes Konferenzdolmetschen. Anforderungen und Erwartungen der Benutzer. Endbericht, im Auftrag von AIIC", [w:] SRZ Stadt- und Regionalforschung: Wien.

Moser-Mercer, B., 2000, „Simultaneous interpreting: cognitive potential and limitations", [w:] Interpreting, nr 5(2), s. 83-94.

Moser-Mercer, B., 2007, „Global cognition: Training a new breed of interpreter trainers", [w:] Interpreting studies and beyond, F. Pöchhacker, A. Lykke Jakobsen, I.M. Mees (red.), Copenhagen, s. 89-101.

Moser-Mercer, B., 2008, „Skill acquisition in interpreting”, [w:] The interpreter and translator trainer, $\mathrm{nr} 2(1)$, s. 1-28.

Pöchhacker, F., 2000, „The Community Interpreter's Task: Self-Perception and Provider Views", [w:] The Critical Link 2: Interpreters in the Community, R. Roberts, S.E. Carr (red.), Amsterdam-Philadephia, s. 49-65.

Pöchhacker, F., 2001, „Quality Assessment in Conference and Community Interpreting", [w:] Meta, $\mathrm{nr}$ 46(2), s. 410-425.

Pöchhacker, F., 2004, Introducing interpreting studies, London - New York.

Pöchhacker, F., 2013, „Researching quality: a two-pronged approach”, [w:] Quality in interpreting: Widening the scope, t. 1, O. García Becerra, E. Macarena Pradas Macías, R. Barranco-Droege (red.), Granada, s. $33-56$.

Riccardi, A., 2002, „Evaluation in Interpretation: Macrocriteria and Microcriteria", [w:] Teaching Translation and Interpreting 4. Building Bridges, E. Hung (red.), Amsterdam-Philadephia, s. 115-126.

Sawyer, D., 2004, Fundamental Aspects of Interpreter Education: Curriculum and Assessment, Amsterdam-Philadelphia.

Tryuk, M., 2012, „Ocena jakości w tłumaczeniu ustnym. Konieczny etap kształcenia tłumaczy konferencyjnych", [w:] Lingwistyka Stosowana, $\mathrm{nr}$ 6, s. 45-55.

Viezzi, M., 1996, Aspetti della Qualita in Interpretazione, Trieste: SSLMIT. 


\section{Interpreting: quality and assessment scales}

\section{Summary}

Interpreting is a social phenomenon that is performed in a specific situational (and cultural) context. Effective communication plays here an essential role, whereas the assessment of this effectiveness cannot be reduced exclusively to the assessment of linguistic parameters. In this paper, two assessment scales will be presented that aim at (measurable) assessment of interpreting and can be applied as a tool in teaching interpreting as well as the assessment scale propounded by the article author on the basis of her own experience in teaching interpreting.

Keywords: interpreting, teaching translation and interpreting, assessment, competence, quality 